Reinhard Heun ${ }^{1 *}$

\title{
Increased Risk of Attempted and Completed Suicide in Obsessive Compulsive Disorder: A Systematic Review of Follow-up Studies
}

\author{
'University of Bonn, Germany \\ *email: globalpsychiatryagmx.com
}

DOI: 10.2478/gp-2018-0009

Received: 30 December 2017; Accepted: 5 September 2018

\begin{abstract}
Obsessive compulsive disorder (OCD) is a severe, often long-term mental disorder. It may be independent from, or comorbid with other mental disorders, especially depression and anxiety disorders. Suicidal thoughts, ideations and ruminations are prevalent in subjects with OCD, but it is not yet clear if the incidences of attempted and completed suicides have increased in comparison with the general population and with other psychiatric disorders.

Methods: We conducted a systematic literature search on the incidence of suicide attempts and completed suicides in subjects with $O C D$. Search terms for Pubmed and Medline were OCD and suicide. We selected papers providing follow-up data on the incidence of attempted and completed suicide in OCD.

Results: 404 papers were initially identified. Only 8 papers covering six studies provided prospective data on attempted or completed suicide over a defined period in subjects with OCD, four studies included control subjects. Two studies providing follow-up data were limited to high-risk samples and did not provide enough data on the incidence of suicide in comparison with the general population. The conclusion that there is an increased risk of attempted and completed suicides in OCD can only be based on one large Swedish National Registry sample with an up to 44 year follow up. Psychiatric comorbidity is the most relevant risk factor for suicide.

Conclusions: Even though some studies report an increased incidence of attempted and completed suicides in OCD patients from selected high risk samples, the evidence from population based studies is mostly based on one large Swedish study. More long-term studies in the general population with a reduced risk of subject attrition are needed. Using a clear definition and assessment of suicidal behaviour and a common time-frame would improve the comparability of future studies.
\end{abstract}

\section{Keywords}

Obsessive-compulsive disorder, OCD, suicide, completed suicide, suicide attempt, suicidal behaviour, follow-up, incidence, epidemiology

\section{INTRODUCTION}

\section{Suicidality and mental health}

Suicidality is common in the general population, and even more common in patients with mental health disorders (Hollander et al 1996/7, Batterham et al. 2017). Suicidality describes a spectrum from suicidal thoughts, ruminations, suicide ideations, suicide planning, suicide attempts and completed suicide. In individual subjects, suicidal thoughts, suicide ideations and intentions usually precede attempted and completed suicide. Subjects with previous thoughts of suicide and suicidal intentions may be more likely to make a suicide attempt. Subjects with previous suicide attempts may be more likely to perform new acts of suicide including further attempts and competed suicide.
However, even though this might be assumed in general, the proportion of subjects that go from one to the next stage may vary in different mental disorders. Cho et al. (2016) observed that the associations between different anxiety disorders and suicidal thoughts were different from associations of other individual disorders with suicidal attempt. Thus, subjects with OCD may have an increased prevalence of suicidal thoughts and ruminations but may not necessarily have an increased risk of suicide.

\section{Obsessive compulsive disorders and suicidality}

Obsessive compulsive disorders are common, often longterm disorders in the general population. The one monthprevalence was $1.1 \%$ in the British National Psychiatric Morbidity Survey of 2000 (Torres et al. 2006). OCD may appear independently or comorbid with other mental health 
disorders, especially depression and anxiety (Chaudhary et al. 2016, Chui et al. 1996, Torres et al. 2006).

Obsessive compulsive disorders are often stressful for the patients and their relatives. Suicidal thoughts, ideations and intentions can be a part of the obsessive ruminations experienced by patients with OCD. These can lead to severe and constant frustration and, consequently, may cause or add to the wish to end one's life. OCD has been associated with suicidal ideations (De Berardis et al. 2015). Suicide ideations were common in college students with OCD; however, most of the suicidal ideations were associated with symptoms of depression (Huz et al. 2016). In contrast, Gupta et al. (2014) observed that suicide ideations were highly prevalent in patients with OCD; and although depression may be a contributory factor for suicidal ideations in patients with OCD, it was not the sole risk factor for suicidal ideations.

In a recent large multinational study, suicidal ideation within the last month was reported by $6.4 \%(n=200)$ of patients with OCD, a lifetime history of previous suicide attempts was observed in 9.0\% $(\mathrm{n}=314)$ (Brakoulias et al. 2017). Crosssectional studies reveal that OCD is not only associated with a high risk of depression but also of recent suicidal behaviour (Chaudhary et al. 2016). OCD is common among adolescents in India; it is associated with ADHD, sexual abuse, psychological distress, poorer academic performance and suicidal behaviour (Jaisoorya et al. 2015).

In the American Epidemiological Catchment Area Study, OCD - both in its uncomplicated and comorbid form - had significantly higher rates of childhood conduct symptoms, adult antisocial personality disorder problems, and of suicide attempts than did 'no or any other psychiatric disorders' (the latter include all psychiatric disorders except schizophrenia without individual disorders or numbers being given, Hollander et al. 1996/7).

In contrast to this, some studies have indicated that the risk of suicide may be reduced in comparison to other mental health disorders such as depression, bipolar disorder and schizophrenia (Coryell 1981). A systematic review and metaanalysis by Kanwar et al. (2013) provided evidence that the rates of suicides are higher in patients with any type of anxiety disorders compared to the subjects without anxiety disorders, except those with OCD who had the same suicide rates as those without OCD.

Due to these conflicting publications, the present study intends to evaluate the risk of attempted and completed suicide in patients with OCD. We excluded studies on suicidal ideation, suicidal thoughts and ruminations in OCD, as they may not provide consistent information on the actual suicidal behaviour in subjects with OCD. Previous suicide attempts may be more often reported by subjects with severe OCD than by controls. This may result in an awareness, or a hindsight bias, that is, the increased awareness of subjects with severe OCD of their previous suicide attempts. A selection bias might be caused by a higher admission or specialist care referral rate for OCD subjects with previous suicide attempts.

To avoid hindsight, awareness, recall bias and selection bias, we did not include cross-sectional studies where the risk factor, that is, OCD is assessed at the same time as the outcome, that is, suicidal attempts. Thus, the present systematic review will focus on the prospective follow-up studies assessing the risk of suicidal behaviour, that is, suicide attempts and completed suicide in subjects with OCD in comparison to that of the general population or to that of subjects with other mental disorders. We included suicide attempts in our analysis as completed suicide is luckily a very rare event in prospective studies.

\section{MATERIAL AND METHODS}

\section{Literature search and identification}

We performed a systematic review on the incidence of attempted and completed suicide in patients with obsessive compulsive disorders. We performed a literature research in Pubmed and Medline using the search terms [obsessivecompulsive disorder or OCD] AND suicide in November 2017.

We used the following inclusion criteria: English language, papers providing data on the incidence of suicidal events, that is, attempted and completed suicide over a specified time period.

We excluded non-English papers due to our language limitations. Editorials, reviews, case reports, were excluded as they do not provide original data on the suicide risk in OCD. Papers on suicidal thoughts, ideations and ruminations on patients and controls were excluded as they do not provide an adequate assessment of suicide risks.

We excluded papers which focused on retrospective assessment of suicidal events by patients as such information is very much prone to a hindsight and awareness bias. Patients with a history of suicide might also be more prone to be admitted to hospitals, thus creating a selection bias. 


\section{Data extraction}

The following information was extracted from the papers: authors, year of publication, country of publication, study focus, study type, subjects investigated, their gender, their age (mean), the assessments performed, the outcomes of the assessments, the study results, the study conclusions, the limitations and possible bias of the studies. The biases were assessed using the Cochrane criteria (Higgins et al. 2017).

\section{RESULTS}

\section{Outcome of literature search}

Using the above mentioned search criteria (that is, $\mathrm{OCD}$ and suicide) in Pubmed and Medline, 404 papers on obsessive compulsive disorder and suicide were initially identified in November 2018. Two other papers were later identified through the reference list of the full papers received as below. Of the 404 paper, we screened all the available titles and abstracts for possible eligibility. We excluded the following articles:

- 63 non-English articles

- 35 review papers, mostly on specific medications for OCD

- Nine case reports were excluded

- 173 other papers included the search terms but did not focus on the interaction of OCD and suicide, these covered other issues and diseases

- 31 papers focussed on suicidal ideations only

- 22 papers reported on suicidal thoughts, but did not cover suicidal behaviours including attempted or completed suicides

We finally identified 73 papers, that is, 71 plus two papers from the reference lists of other papers, which might focus on the prevalence or incidence of suicidal acts in subjects with OCD. The PDF or full prints of these 73 eligible papers were received and assessed for their relevance to the study questions.

- 42 of these papers included no relevant data on the association of OCD and suicidality.

- 23 papers were excluded as they only provided crosssectional or retrospective data on the association of OCD and suicidal behaviour, and thus, were prone to selection and hindsight bias.

Finally, eight papers were identified that provided prospective estimates of the incidence of suicidal events, that is, provided data on attempted or completed suicide over a defined observation period. These reports were included in the final review.

- Two papers were secondary updated reports of already published data with minor changes of the numbers; for clarity only the initial of both reports were included in the systematic review (see table 1).

Table 1 provides a summary of the six research studies finally included in the systematic analysis.

\section{Incidence of attempted and completed suicide}

In our review, we observed that the incidence of suicide attempts in OCD subjects varies considerably between studies and samples.

The rates of attempted suicide were increased in OCD subjects identified in the general population versus control subjects, even though the first three studies did not reveal statistical significance:

- $0.16 \% /$ year in subjects with full OCD and OCD spectrum disorders (OCS) versus $0.1 \% /$ year in control subjects (Angst et al. 2005, update reported by Fineberg et al. 2013, difference $\mathrm{p}>0.05$ )

- $0.48 \%$ /year in OCD subjects versus $0.1 \%$ / year without any anxiety disorder (Bolton et al. 2008, difference $\mathrm{p}>$ $0.05)$

- $2.2 \%$ /year in OCD subjects versus $0.27 \%$ in the total sample at risk (Sareen et al 2005, update reported ten Have 2009, p > 0.05)

- $\quad 0.53 \% /$ year in OCD subjects versus $0.11 \%$ /year in control subjects (Fernandez et al. 2017). This latter study is the only one to show a statistically significant increase of suicide attempts in subjects with OCD. Assuming a 22year average follow up-period, the Odds ratio was $\mathrm{OR}=$ $5.45,95 \%$ confidence interval $\mathrm{CI}=5.24-5.67$.

The rates of attempted suicides were usually high in patients in treatment for OCD even though there were no control samples investigated, that is, neither OCD subjects from the general population nor subject without OCD:

- $\quad 1.2 \% /$ year (OCD clinic sample, Alonso et al. 2010)

- $2.0 \% /$ year suicide attempts that led to hospitalisation before and $0.57 \%$ after surgery in OCD subjects treated with capsulotomy (Rueck et al. 2017)

Completed suicides were rare in all studies in the general population, thus showing no significant increases of completed suicides in OCD subjects versus controls in all, but one study. Assuming an average observation period of 22 
GLOBAL PSYCHIATRY - Increased Risk of Attempted and Completed Suicide in Obsessive Compulsive Disorder:

A Systematic Review of Follow-up Studies

Table 1. Follow-up studies assessing risk of suicide attempts and completed suicide in subjects with OCD and controls

\begin{tabular}{|c|c|c|c|c|c|c|c|}
\hline $\begin{array}{l}\text { Authors } \\
\text { (year) }\end{array}$ & Country & Study focus & Study type & Subjects & Gender & $\begin{array}{c}\text { Age } \\
\text { (mean) }\end{array}$ & Assessment of OCD \\
\hline $\begin{array}{c}\text { Alonso et al. } \\
2010\end{array}$ & Spain & $\begin{array}{c}\text { Suicide } \\
\text { attempts in } \\
\text { subjects with } \\
\text { OCD }\end{array}$ & $\begin{array}{c}\text { Prospective } \\
\text { cohort over 1-6 } \\
\text { years (mean } 4.1 \\
\text { years) }\end{array}$ & $\begin{array}{l}218 \text { subjects } \\
\text { with OCD from } \\
\text { specialized } \\
\text { clinic }\end{array}$ & $\begin{array}{l}57 \% \\
\text { male }\end{array}$ & 31 years & $\begin{array}{c}\text { Diagnostic and } \\
\text { Statistical Manual } \\
\text { of Mental Disorders, } \\
\text { version IV (DSM-IV) }\end{array}$ \\
\hline $\begin{array}{l}\text { Angst et al. } \\
2005 \text {, re- } \\
\text { reported by } \\
\text { Fineberg et } \\
\text { al. } 2013\end{array}$ & Switzerland & $\begin{array}{l}\text { Suicide } \\
\text { attempts in } \\
\text { OCD versus } \\
\text { the remaining } \\
\text { general } \\
\text { population }\end{array}$ & $\begin{array}{l}\text { Prospective } \\
\text { cohort with a } 20 \\
\text { year follow-up }\end{array}$ & $\begin{array}{l}32 \text { cases } \\
\text { with OCD/ } 79 \\
\text { subjects with } \\
\text { Obsessive } \\
\text { compulsive } \\
\text { syndrome } \\
\text { (OCS), } 142 \\
\text { control } \\
\text { subjects } \\
\text { from general } \\
\text { population }\end{array}$ & $\begin{array}{c}37 \% \text { vs. } \\
54 \% \text { vs. } \\
57 \% \\
\text { male }\end{array}$ & $\begin{array}{l}20 \text { years } \\
\text { at intake }\end{array}$ & $\begin{array}{l}\text { DSM-IV for OCD, } \\
\text { Obsessive Compulsive } \\
\text { Syndrome (OCS) } \\
\text { indicating the same } \\
\text { symptoms but less } \\
\text { subjective distress. }\end{array}$ \\
\hline $\begin{array}{c}\text { Bolton et al. } \\
2008\end{array}$ & Canada & $\begin{array}{l}\text { Suicide } \\
\text { attempts in } \\
\text { OCD }\end{array}$ & $\begin{array}{c}\text { prospective } \\
\text { cohort of } 1920 \\
\text { subjects, } \\
\text { Baltimore } \\
\text { Epidemiological } \\
\text { Catchment Area } \\
\text { survey } 13 \text { year } \\
\text { follow up }\end{array}$ & $\begin{array}{l}48 \text { subjects } \\
\text { with OCD } \\
\text { without } \\
\text { any history } \\
\text { of suicide } \\
\text { attempts, } \\
1229 \text { subjects } \\
\text { without } \\
\text { any anxiety } \\
\text { disorder }\end{array}$ & $\begin{array}{l}37 \% \\
\text { male }\end{array}$ & $\begin{array}{l}\text { Not } \\
\text { given }\end{array}$ & $\begin{array}{l}\text { DSM-III diagnosis } \\
\text { after structured } \\
\text { interview }\end{array}$ \\
\hline $\begin{array}{l}\text { Fernandez } \\
\text { de la Cruz } \\
\text { et al. } 2017\end{array}$ & Sweden & $\begin{array}{l}\text { Suicide } \\
\text { attempts in } \\
\text { OCD versus } \\
\text { general } \\
\text { population }\end{array}$ & $\begin{array}{l}\text { Cohort study } \\
\text { using register } \\
\text { data (National } \\
\text { Patient register) } \\
\text { follow-up up to } \\
44 \text { years }\end{array}$ & $\begin{array}{l}36788 \text { patients } \\
\text { with OCD } \\
\text { and } 387880 \\
\text { matched } \\
\text { controls }\end{array}$ & $\begin{array}{l}43 \% \\
\text { male }\end{array}$ & $\begin{array}{l}43 \text { years } \\
\text { lage at } \\
\text { death by } \\
\text { suicide), } \\
30 \text { age } \\
\text { at first } \\
\text { suicide } \\
\text { attempt }\end{array}$ & $\begin{array}{c}\text { International } \\
\text { Classification of } \\
\text { Diseases (8th to 10th } \\
\text { revision) }\end{array}$ \\
\hline $\begin{array}{c}\text { Rueck et al. } \\
2017\end{array}$ & Sweden & $\begin{array}{l}\text { Suicide in } \\
\text { OCD subjects } \\
\text { treated with } \\
\text { capsulotomy }\end{array}$ & $\begin{array}{c}\text { Prospective } \\
\text { cohort study } \\
\text { using register } \\
\text { data wih a follow } \\
\text { up of up to } 43 \\
\text { years }\end{array}$ & $\begin{array}{l}70 \text { patients } \\
\text { with } \\
\text { capsulotomy }\end{array}$ & $\begin{array}{l}53 \% \\
\text { male }\end{array}$ & $\begin{array}{l}68 \text { years } \\
\text { old at } \\
\text { the age } \\
\text { of death }\end{array}$ & $\begin{array}{c}\text { International } \\
\text { Classification of } \\
\text { Diseases (8th to 10th } \\
\text { revision) }\end{array}$ \\
\hline $\begin{array}{l}\text { Sareen et } \\
\text { al. } 2005 . \\
\text { update } \\
\text { reported ten } \\
\text { Have et al. } \\
2009\end{array}$ & Netherlands & $\begin{array}{c}\text { Suicide } \\
\text { attempts } \\
\text { in general } \\
\text { population } \\
\text { including OCD } \\
\text { subjects }\end{array}$ & $\begin{array}{l}\text { Prospective } \\
\text { cohort with } 3 \\
\text { year follow up }\end{array}$ & $\begin{array}{l}4670 \text { subjects } \\
\text { with completed } \\
\text { follow up }\end{array}$ & $\begin{array}{l}\text { Not } \\
\text { given }\end{array}$ & $\begin{array}{l}\text { Not } \\
\text { given }\end{array}$ & $\begin{array}{c}\text { Composite } \\
\text { International } \\
\text { Diagnostic Interview } \\
\text { providing DSM-III } \\
\text { revised diagnosis }\end{array}$ \\
\hline
\end{tabular}


Table 1. Follow-up studies assessing risk of suicide attempts and completed suicide in subjects with OCD and controls

\begin{tabular}{|c|c|c|c|c|c|c|}
\hline $\begin{array}{l}\text { Authors } \\
\text { (year) }\end{array}$ & Outcome & Study result & Conclusions & $\begin{array}{l}\text { Predictors of suicide } \\
\text { in } O C D\end{array}$ & Limitations & $\begin{array}{l}\text { Possible } \\
\text { bias }\end{array}$ \\
\hline $\begin{array}{c}\text { Alonso et al. } \\
2010\end{array}$ & $\begin{array}{l}11 \text { suicide } \\
\text { attempts, } 2 \\
\text { completed } \\
\text { suicides }\end{array}$ & $\begin{array}{c}\text { 2/ } 218(0.9 \%) \\
\text { committed, } \\
11 / 218(5 \%) \\
\text { attempted } \\
\text { suicide within } \\
\text { the observation } \\
\text { period }\end{array}$ & $\begin{array}{l}\text { Suicide is not highly } \\
\text { common but should } \\
\text { not be disregarded. }\end{array}$ & $\begin{array}{l}\text { Suicide behaviour } \\
\text { associated with being } \\
\text { unmarried, history } \\
\text { of affective disorders } \\
\text { and symmetry/ } \\
\text { ordering obsessions. }\end{array}$ & $\begin{array}{l}\text { Selected } \\
\text { intensively } \\
\text { treated clinic } \\
\text { sample }\end{array}$ & $\begin{array}{l}\text { Selection } \\
\text { bias }\end{array}$ \\
\hline $\begin{array}{l}\text { Angst et al. } \\
\text { 2005, re- } \\
\text { reported by } \\
\text { Fineberg et } \\
\text { al. } 2013\end{array}$ & $\begin{array}{l}1 \text { patients with } \\
\text { OCD/OCS and } 3 \\
\text { control subjects } \\
\text { attempted } \\
\text { suicide in } 20 \\
\text { years }\end{array}$ & $\begin{array}{c}3.1 \% \text { of } \\
\text { subjects } \\
\text { with OCD or } \\
\text { OCS (without } \\
\text { comorbidity) } \\
\text { and } 2.3 \% \\
\text { control subjects } \\
\text { had attempted } \\
\text { suicide }\end{array}$ & $\begin{array}{c}\text { Suicide rates } \\
\text { not significantly } \\
\text { increased in } \\
\text { subjects with pure, } \\
\text { non-comorbid OCD/ } \\
\text { OCS. }\end{array}$ & $\begin{array}{c}\text { Comorbid OCD/ } \\
\text { OCS was associated } \\
\text { with significantly } \\
\text { higher levels of } \\
\text { treatment seeking, } \\
\text { impairment,distress } \\
\text { and suicidality } \\
\text { compared with pure } \\
\text { OCD/OCS. }\end{array}$ & $\begin{array}{l}\text { Selected } \\
\text { healthy } \\
\text { subjects at } \\
\text { intake. }\end{array}$ & $\begin{array}{l}\text { Minor } \\
\text { selection } \\
\text { bias, some } \\
\text { study } \\
\text { attrition. }\end{array}$ \\
\hline $\begin{array}{l}\text { Bolton et al. } \\
2008\end{array}$ & $\begin{array}{c}3 \text { suicide }(6.3 \%) \\
\text { attempts in } O C D \\
\text { subjects over } \\
13 \text { years, } 16 \text { in } \\
1229 \text { subjects } \\
\text { without anxiety } \\
\text { disorders }\end{array}$ & $\begin{array}{l}\text { OCD did not } \\
\text { significantly } \\
\text { increased in } \\
\text { subjects who } \\
\text { attempted } \\
\text { suicide. }\end{array}$ & $\begin{array}{c}\text { Any anxiety } \\
\text { disorders at } \\
\text { baseline was } \\
\text { significantly } \\
\text { associated with } \\
\text { subsequent onset } \\
\text { suicide attempts } \\
\text { ladjusted odds ratio } \\
2.20 \text {. }\end{array}$ & $\begin{array}{c}\text { Predictors not } \\
\text { individually assessed } \\
\text { for OCD. }\end{array}$ & $\begin{array}{l}\text { No specific } \\
\text { assessment } \\
\text { for OCD. }\end{array}$ & $\begin{array}{l}\text { Low power } \\
\text { for OCD } \\
\text { subsample }\end{array}$ \\
\hline $\begin{array}{l}\text { Fernandez } \\
\text { de la Cruz } \\
\text { et al. } 2017\end{array}$ & $\begin{array}{l}4297 \text { suicide } \\
\text { attempts } \\
(11.7 \%) \text { and } 545 \\
\text { suicides }(1.5 \%) \\
\text { according } \\
\text { to Swedish } \\
\text { Cause of death } \\
\text { Register }\end{array}$ & $\begin{array}{l}\text { Increased } \\
\text { risk of suicide } \\
\text { and suicide } \\
\text { attempts (OR } \\
9.8 \text { resp. 5.5) } \\
\text { in comparison } \\
\text { with controls. }\end{array}$ & $\begin{array}{l}\text { Increased risk of } \\
\text { suicide attempts } \\
\text { and completed } \\
\text { suicide in OCD even } \\
\text { after accounting } \\
\text { for psychiatric } \\
\text { comorbidities. }\end{array}$ & $\begin{array}{l}\text { A previous suicide } \\
\text { attempt, comorbid } \\
\text { substance abuse or } \\
\text { personality disorder } \\
\text { increased the risk of } \\
\text { death by suicide }\end{array}$ & $\begin{array}{l}\text { Changes of } \\
\text { diagnostic } \\
\text { criteria over } \\
\text { time, some } \\
\text { attrition due } \\
\text { to loss to } \\
\text { register }\end{array}$ & $\begin{array}{c}\text { Minor } \\
\text { diagnostic } \\
\text { imprecision } \\
\text { but no } \\
\text { major bias } \\
\text { likely }\end{array}$ \\
\hline $\begin{array}{c}\text { Rueck et al. } \\
2017\end{array}$ & $\begin{array}{c}2 \text { out of } 29 \\
\text { deceased } \\
\text { subject had died } \\
\text { of suicide (plus } \\
\text { one suspected } \\
\text { suicide) }\end{array}$ & $\begin{array}{l}\text { There is a } \\
\text { relevant suicide } \\
\text { risk even } \\
\text { though there is } \\
\text { no comparison } \\
\text { with control } \\
\text { subjects. }\end{array}$ & $\begin{array}{l}\text { Attention needs to } \\
\text { be given to possible } \\
\text { suicide in OCD. }\end{array}$ & $\begin{array}{c}\text { Predictors impossible } \\
\text { to assess due to low } \\
\text { sample size. }\end{array}$ & $\begin{array}{l}\text { Highly } \\
\text { selected } \\
\text { sample }\end{array}$ & $\begin{array}{l}\text { Selection } \\
\text { bias likely }\end{array}$ \\
\hline $\begin{array}{l}\text { Sareen et } \\
\text { al. } 2005 . \\
\text { update } \\
\text { reported ten } \\
\text { Have et al. } \\
2009\end{array}$ & $\begin{array}{l}2 \text { out of } 31 \text { OCD } \\
\text { subjects }(3.3 \%) \\
\text { and } 39 / 4670 \\
\text { of all subjects } \\
\text { at risk }(0.83 \%) \\
\text { attempted } \\
\text { suicide during } \\
\text { follow up. }\end{array}$ & $\begin{array}{l}\text { Non-significant } \\
\text { increase } \\
\text { in suicide } \\
\text { attempts in } \\
\text { subjects wth } \\
\text { OCD. }\end{array}$ & $\begin{array}{c}\text { No clear conclusion } \\
\text { possible }\end{array}$ & $\begin{array}{c}\text { Predictors not } \\
\text { assessed for } O C D \text {. }\end{array}$ & $\begin{array}{l}\text { Limited } \\
\text { power due to } \\
\text { the rarity of } \\
\text { the possible } \\
\text { event. }\end{array}$ & $\begin{array}{l}\text { Lack of } \\
\text { statistical } \\
\text { power }\end{array}$ \\
\hline
\end{tabular}


years, Fernandez et al. (2017) observed significantly increased rates of completed suicides in OCD subjects versus control subjects, that is, $0.067 \% /$ year in OCD subjects versus $0.0072 \%$ in control subjects.

Suicides were relatively high in inpatient samples (even thought there were no control samples assessed):

- $\quad 0.22 \% / y e a r$ in treated OCD patients (Alonso et al. 2010)

- $\quad 0.15 \% / y e a r$ in an OCD sample treated with capsulotomy (assuming an average observation period of 28 years, Rueck et al. 2017)

\section{Risk factors of attempted and completed suicide in OCD}

Psychiatric comorbidity seems to be the most common risk factor for attempted and completed suicide: Alonso et al. (2010) revealed that suicidal behaviour in OCD subjects was associated with being unmarried, symmetry/ordering obsessions and a history of affective disorders. Angst et al. (2005) reported that comorbid OCD/OCS was associated with significantly higher levels of treatment seeking, impairment, distress and suicidality compared with pure OCD/OCS. According to Fernandez de la Cruz et al. (2017), a previous suicide attempt, comorbid substance abuse or personality disorder increased the risk of death by suicide in subjects with OCD.

Bolton et al. 2008 showed that any anxiety disorders at baseline was significantly associated with subsequent onset suicide attempts (adjusted odds ratio 2.20, however, predictors were not individually assessed for subjects with OCD. Studies by Rueck et al. 2017 and Sareen et al, (2005) did not allow to assess risk factors of suicidal behaviour in OCD due to the low samples sizes of subjects at risk.

\section{DISCUSSION}

\section{General observations of the systematic review}

The one large Swedish national register study showed clear evidence that the rate of attempted and completed suicide is significantly higher in subjects with $\mathrm{OC}$ as compared to control subjects from the general population (Fernandez de la Cruz et al. 2017). The numbers of subjects, the duration of observations and the comprehensiveness of patient and control sample identification are impressive and support the validity of the evidence.

Other prospective studies included in our review that provided data on the suicide risk in OCD were in support of this observation. They showed non-significant trends in the same direction (Angst et al. 2005, Bolton et al. 2008, Sareen et al. 2005). However, due to the low rates of attempted and completed suicide combined with the low number of subjects at risk, the power of these studies is far too low to reach any statistical significance. The studies by Alonso at al. (2010) and Rueck et al. (2017) can also be seen as supportive for an increased risk of suicide in OCD as they provide relatively high rates of suicide compared to the above mentioned studies, but their relevance is limited due to their lack of a control group.

The observed increase of attempted and completed suicide in prospective studies, especially the one from Fernandez et al. (2017), is comparable to the reports from previous crosssectional and retrospective studies: Data from 3711 adult patients with primary OCD that came from several countries indicated that suicidal ideation within the last month was reported by $6.4 \%(n=200)$ of patients with OCD and a lifetime history of suicide attempt was observed in 9.0\% (n = 314) (Brakoulias et al. 2017). In agreement, patients with a previous suicide attempt had significantly higher rates of comorbid psychiatric disorders (Dell'Osso et al. 2017). This data were supported by the studies reviewed by Angelakis et al. (2015).

This recent review on OCD and suicidality was performed by Angelakis et al. (2015). This review included the literature up to March 2014, however, it focussed mostly on suicidal thoughts and ideations and could not include the most recent prospective studies. This review revealed a significant association between OCD and suicide through ideation and suicide attempts, but did not provide sufficient information about completed suicide. Most of the studies used by the authors were cross sectional, thus being prone to a selection and hindsight bias. Some prospective studies were used twice reporting slightly different figures, even though they referred to identical or overlapping samples. For clarity, we used the initial publication of both prospective studies (Angst et al. 2005, update reported by Fineberg $t$ al. 2013; Sareen et al. 2005, update reported by ten Have et al. 2009). The updates were not included a second time as they provided highly redundant information that did not affect the general outcomes of the initial reports, but the double-presentations would give the false impression of a higher number of relevant studies and samples.

The observed association between co-morbidity and suicidality has also been observed in other disorders (AlAsadi et al. 2014, 2015). Adolescents with OCD have increased numbers of suicidal ideations, the number of previous suicide 
attempts was found to be lower than that of other patients with mental disorders (Apter et al. (2003). However, such claims are based on cross sectional and retrospective studies that are prone to selection and awareness bias. Sadly, there are no follow up studies that have included different psychiatric disorders including OCD and would allow a relevant valid comparison.

\section{Risk factors for suicidality in OCD}

Psychiatric comorbidity seems to be the most common risk factor for attempted and completed suicide. According to Fernandez de la Cruz et al. (2017), a previous suicide attempt, comorbid substance abuse or personality disorder increased the risk of death by suicide in subjects with OCD. Two smaller studies supported the relevance of additional psychiatric comorbidity but also identified other risk factors for suicide behaviour in OCD, that is, being unmarried, symmetry/ ordering obsessions and a history of affective disorders (Alonso et al. 2010). Angst et al. 2005 reported psychiatric comorbidity to be associated with significantly higher levels of treatment seeking, impairment, distress and suicidality compared with pure OCD/OCS.

The risk factors identified in these prospective studies are confirmed through reports from cross sectional studies, which usually have more subjects at risks and thus a higher statistical power, but sadly are more prone to selection and awareness bias:

In agreements with the above studies, the prevalence of suicidal thought was higher for those with more than one psychiatric disorders (Al-Asadi et al. 2015). According to Hung et al. (2010), depression and anxiety symptoms contribute significantly to suicidal ideation among patients with OCD. According to Kamath et al. (2007), depression and hopelessness were the major correlates of suicidal behaviour in OCD. Chia et al. (1996) also assumed that depression was a main contributing factor in two of the subjects who had committed suicide. Torres et al. (2011) assessed 582 OCD patients from Brazil; 36 percent of the OCD patients reported lifetime suicidal thoughts, $20 \%$ had made suicidal plans, $11 \%$ had already attempted suicide, and $10 \%$ presented current suicidal thoughts. In the logistic regression, only lifetime major depressive disorder and posttraumatic stress disorder (PTSD) remained independently associated with all the aspects of suicidal behaviours.

Angelakis et al. (2015) identified more predictors of suicidality in OCD: Comorbid Axis I disorders, increased severity of comorbid depressive and anxiety symptoms, increased severity of obsessions, feelings of hopelessness and past history of suicide attempts were associated with worsening levels of suicidality in OCD. In OCD patients without current depression, suicide ideations were associated with female gender, presence of comorbid psychiatric illness (other than depression), contamination obsessions and cleaning/washing compulsions (Gupta et al. 2014).

Similar observations were also found in the presence of one or more obsessive compulsive symptoms that were associated with an increased odds ratio of suicide risk of approximately 2.4 in a sample of 474 students; although this was no longer a significant risk factor when controlling for depressive symptoms (Huz et al. 2016). Of the OCS assessed, only obsessions about speaking or acting violently as well as depression remained independent risk factors for suicidality. In agreement, Ching et al. (2017) observed that violent obsessions were associated with suicidality in an OCDanalog sample of college students. It might be argued that these associations were driven by the associations between OCD and suicidal thoughts, and suicide attempts were retrospectively assessed and thus were prone to hindsight and awareness bias.

\section{Conclusions and limitations}

The conclusion that there is an increased risk of suicide in OCD and is mainly based on one prospective study (Fernandez de la Cruz et al. 2017), which prospectively assessed the attempted and completed suicide. This study is also the only prospective study that had enough statistical power to identify some predictors of suicide in OCD. Other studies (Angst et al. 2005, Alonso et al. 2010) are supportive of the outcome but they are usually based on smaller samples of OCD subjects or suffer a lack of a reasonable control group. As completed suicide luckily is a very rare event, none of the studies is sufficiently powered to calculate reasonably accurate risks, that is expected incidence data for suicide in OCD with low statistical confidence intervals. Previous studies that show an increase of suicidality in OCD focussed on suicidal thoughts and ideations, but less on suicide attempts or completed suicides.

To be able to generalize the results from this Swedish Register based study to other countries, one would need to access similarly large national patients' and mortality registers. To be able to compare the results of future studies on the relationship of OCD and suicidality, it would be helpful if such studies would use similar diagnostic criteria for psychiatric diagnoses 
and suicidality, use comparable assessment tools for all types of suicidality, and apply predetermined comparable time-frames.

\section{ACKNOWLEDGEMENTS}

We are extremely grateful to Meara Brooks and Mary Hickman for their help with the literature search.

\section{CONFLICT OF INTEREST}

none

\section{ETHICAL APPROVAL}

This literature review did not require any ethical approval.

\section{INFORMED CONSENT}

This literature review did not require any informed consent.

\section{REFERENCES}

Al-Asadi AM, Klein B, Meyer D. Comorbidity structure of psychological disorders in the online e-PASS data as predictors of psychosocial adjustment measures: psychological distress, adequate social support, self-confidence, quality of life, and suicidal ideation. J Med Internet Res. 2014 Oct 28;16(10):e248. doi: 10.2196/jmir.3591.

Al-Asadi AM, Klein B, Meyer D. Multiple comorbidities of 21 psychological disorders and relationships with psychosocial variables: a study of the online assessment and diagnostic system within a web-based population. J Med Internet Res. 2015 Feb 26;17(2):e55. doi: 10.2196/jmir.4143.

Alonso P, Segalàs C, Real E, Pertusa A, Labad J, Jiménez-Murcia S, Jaurrieta N, Bueno B, Vallejo J, Menchón JM. Suicide in patients treated for obsessive-compulsive disorder: a prospective followup study. Affect Disord. 2010 Aug;124(3):300-8. doi: 10.1016/j. jad.2009.12.001.

Angelakis I, Gooding P, Tarrier N, Panagioti M. Suicidality in obsessive compulsive disorder (OCD): a systematic review and meta-analysis. Clin Psychol Rev. 2015 Jul;39:1-15. doi: 10.1016/j. cpr.2015.03.002.

Angst J, Gamma A, Endrass J, Hantouche E, Goodwin R, Ajdacic V, Eich D, Rössler W. Obsessive-compulsive syndromes and disorders: significance of comorbidity with bipolar and anxiety syndromes. Eur Arch Psychiatry Clin Neurosci. 2005 Feb;255(1):6571.

Apter A, Horesh N, Gothelf D, Zalsman G, Erlich Z, Soreni N, Weizman A. Depression and suicidal behavior in adolescent inpatients with obsessive compulsive disorder. J Affect Disord. 2003 Jul;75(2):181-9.
Batterham PJ, Calear AL, Christensen H, Carragher N, Sunderland M. Independent Effects of Mental Disorders on Suicidal Behavior in the Community. Suicide Life Threat Behav. 2017 Aug 7. doi: 10.1111/sltb.12379.

Beasley CM Jr, Potvin JH, Masica DN, Wheadon DE, Dornseif BE, Genduso LA. Fluoxetine: no association with suicidality in obsessivecompulsive disorder. J Affect Disord. 1992 Jan;24(1):1-10.

Bland RC, Newman SC, Dyck RJ, Orn H. Prevalence of psychiatric disorders and suicide attempts in a prison population. Can J Psychiatry. 1990 Jun;35(5):407-13.

Bolton JM, Cox BJ, Afifi TO, Enns MW, Bienvenu OJ, Sareen J. Anxiety disorders and risk for suicide attempts: findings from the Baltimore Epidemiologic Catchment area follow-up study. Depress Anxiety. 2008;25(6):477-81.

Brakoulias V, Starcevic V, Belloch A, Brown C, Ferrao YA, Fontenelle LF, Lochner C, Marazziti D, Matsunaga H, Miguel EC, Reddy YCJ, do Rosario MC, Shavitt RG, Shyam Sundar A, Stein DJ, Torres AR, Viswasam K. Comorbidity, age of onset and suicidality in obsessivecompulsive disorder (OCD): An international collaboration. Compr Psychiatry. 2017;76:79-86. doi: 10.1016/j.comppsych.2017.04.002.

Chaudhary RK, Kumar P, Mishra BP. Depression and risk of suicide in patients with obsessive-compulsive disorder: A hospital-based study. Ind Psychiatry J. 2016 Jul-Dec;25(2):166-170. doi: 10.4103/ ipj.ipj_63_16.

Chia BH A Singapore study of obsessive compulsive disorder. Singapore Med J. 1996 Aug;37(4):402-6

Ching TH, Williams M, Siev J. Violent obsessions are associated with suicidality in an OCD analog sample of college 
students. Cogn Behav Ther. 2017 Mar;46(2):129-140. doi: 10.1080/16506073.2016.1228084.

Cho SJ, Hong JP, Lee JY, Im JS, Na KS, Park JE, Cho MJ. Association between DSM-IV Anxiety Disorders and Suicidal Behaviors in a Community Sample of South Korean Adults. Psychiatry Investig. 2016 Nov; 13(6):595-600.

Coryell W. Obsessive-compulsive disorder and primary unipolar depression. Comparisons of background, family history, course, and mortality. J Nerv Ment Dis. 1981 Apr;169(4):220-4.

De Berardis D, Serroni N, Campanella D, Rapini G, Olivieri L, Feliziani B, Carano A, Valchera A, lasevoli F, Tomasetti C, Mazza M, Fornaro M, Perna G, Di Nicola M, Martinotti G, Di Giannantonio M. Alexithymia, responsibility attitudes and suicide ideation among outpatients with obsessive-compulsive disorder: an exploratory study. Compr Psychiatry. 2015 Apr;58:82-7. doi: 10.1016/j. comppsych.2014.12.016.

Dell'Osso B, Benatti B, Arici C, Palazzo C, Altamura AC, Hollander E, Fineberg N, Stein DJ, Nicolini H, Lanzagorta N, Marazziti D, Pallanti S, van Ameringen M, Lochner C, Karamustafalioglu O, Hranov L, Figee M, Drummond L), Rodriguez Cl, Grant J, Denys D, Menchon JM, Zohar J. Prevalence of suicide attempt and clinical characteristics of suicide attempters with obsessive-compulsive disorder: a report from the International College of ObsessiveCompulsive Spectrum Disorders (ICOCS). CNS Spectr. 2017 Mar 16:1-8. doi: 10.1017/S1092852917000177. [Epub ahead of print]

Fernández de la Cruz L, Rydell M, Runeson B, D’Onofrio BM, Brander G, Rück C, Lichtenstein P, Larsson H, Mataix-Cols D. Suicide in obsessive-compulsive disorder: a populationbased study of 36788 Swedish patients. Mol Psychiatry. 2017 Nov;22(11):1626-1632. doi: 10.1038/mp.2016.115.

Fineberg NA, Hengartner MP, Bergbaum CE, Gale TM, Gamma A, Ajdacic-Gross V, Rössler W, Angst J. A prospective populationbased cohort study of the prevalence, incidence and impact of obsessive-compulsive symptomatology. Int J Psychiatry Clin Pract 2013; 17: 170-178, DOI: 10.3109/13651501.2012.755206

Gupta G, Avasthi A, Grover S, Singh SM. Factors associated with suicidal ideations and suicidal attempts in patients with obsessive compulsive disorder. Asian J Psychiatr. 2014 Dec;12: 140-6.

Higgins JPT, Altman DG. Chapter 8: Assessing risk of bias in included studies. In: Higgins JPT, Green S, editors. Cochrane handbook for systematic reviews of interventions version 5.1. The Cochrane Collaboration; 2017.Available: http://www.cochranehandbook.org/. Accessed 20 September 2017
Hollander E, Greenwald S, Neville D, Johnson J, Hornig CD, Weissman MM. Uncomplicated and comorbid obsessivecompulsive disorder in an epidemiologic sample. Depress Anxiety. 1996-1997;4(3):111-9.

Hung TC, Tang HS, Chiu CH, Chen YY, Chou KR, Chiou HC, Chang HJ. Anxiety, depressive symptom and suicidal ideation of outpatients with obsessive compulsive disorders in Taiwan. J Clin Nurs. 2010 Nov;19(21-22):3092-101. doi: 10.1111/j.1365-2702.2010.03378.x.

Huz I, Nyer M, Dickson C, Farabaugh A, Alpert J, Fava M, Baer L. Obsessive-Compulsive Symptoms as a Risk Factor for Suicidality in U.S. College Students. J Adolesc Health. 2016;58(4):481-484. doi: 10.1016/j.jadohealth.2015.11.011.

Jaisoorya TS, Janardhan Reddy YC, Thennarasu K, Beena KV, Beena M, Jose DC. An epidemological study of obsessive compulsive disorder in adolescents from India. Compr Psychiatry. 2015;61:106-14. doi: 10.1016/j.comppsych.2015.05.003

Kamath P, Reddy YC, Kandavel T. Suicidal behavior in obsessivecompulsive disorder. J Clin Psychiatry. 2007 Nov;68(11):1741-50.

Kanwar A, Malik S, Prokop LJ, Sim LA, Feldstein D, Wang Z, Murad $\mathrm{MH}$. The association between anxiety disorders and suicidal behaviors: a systematic review and meta-analysis. Depress Anxiety. 2013 Oct;30(10):917-29. doi: 10.1002/da.22074.

Rück C, Larsson JK, Mataix-Cols D, Ljung R. A register-based 13-year to 43-year follow-up of 70 patients with obsessivecompulsive disorder treated with capsulotomy. BMJ Open. 2017 Jun 6;7(5):e013133. doi: 10.1136/bmjopen-2016-013133.

Sareen J(1), Cox BJ, Afifi TO, de Graaf R, Asmundson GJ, ten Have $M$, Stein MB. Anxiety disorders and risk for suicidal ideation and suicide attempts: a population-based longitudinal study of adults. Arch Gen Psychiatry. 2005 Nov; 62(11):1249-57.

Torres AR, Prince MJ, Bebbington PE, Bhugra D, Brugha TS, Farrell M, Jenkins R, Lewis G, Meltzer H, Singleton N. Obsessivecompulsive disorder: prevalence, comorbidity, impact, and helpseeking in the British National Psychiatric Morbidity Survey of 2000. Am J Psychiatry. 2006 Nov; 163(11):1978-85.

Torres AR, Ramos-Cerqueira AT, Ferrão YA, Fontenelle LF, do Rosário MC, Miguel EC. Suicidality in obsessive-compulsive disorder: prevalence and relation to symptom dimensions and comorbid conditions. J Clin Psychiatry. 2011 Jan;72(1):17-26 
ten Have M, de Graaf R, van Dorsselaer S, Verdurmen J, van 't Land $H$, Vollebergh W, Beekman A. Incidence and Course of Suicidal Ideation and Suicide Attempts in the General Population. Can J Psychiatry. 2009;54(12):824-833. 